\title{
Human Resources for Tourism and Travel Business in Vietnam
}

\author{
Tran Thi Hien \\ Faculty of Business Administration, Academy of Finance, Vietnam \\ Hoa Huu Cuong \\ Institute for European Studies, Vietnam Academy of Social Sciences, Vietnam
}

Nguyen Thi Phuong Loan

Faculty of Business Administration, Academy of Finance, Vietnam

\section{Do Thi Nang}

Faculty of Business Administration, Academy of Finance, Vietnam

\author{
Le Hoang Anh
}

Faculty of Business Administration, Academy of Finance, Vietnam

Nguyen Quang Sang

Faculty of Business Administration, Academy of Finance, Vietnam

Received: October 2, 2020 Accepted: October 30, 2020 Published: November 10, 2020 doi:10.5296/ber.v10i4.17929

URL: https://doi.org/10.5296/ber.v10i4.17929

\begin{abstract}
Vietnam is facing a shortage in both the quantity and quality of human resources for tourism and travel business. This shortage becomes even more urgent after the ASEAN agreement on the free movement of tourism human resources among Southeast Asian countries. With the trend of extensive international economic integration, increasing digital technology, tourism
\end{abstract}


business activities have also changed. According to the trend of "smart tourism", tourism business enterprises require that human resources must ensure skills, profession and proficiency in using smart tourism management software and technologies. Therefore, tourism training institutions need to quickly approach and apply advanced applications of intelligent technology, artificial intelligence in teaching and practicing. The paper focuses on analyzing the current situation of human resources in tourism and travel industry in Vietnam, the training and retraining of this workforce in the past time. From there, propose some solutions to improve the training and retraining of human resources for tourism and travel business in the future.

Keywords: Tourism, Tourism human resources, Human resources for tourism and travel business

\section{Introduction}

In recent years, Vietnam tourism is on the rise, the number of international tourists coming as well as domestic tourists is increasing. Vietnam tourism is becoming more and more popular in the world, many domestic destinations are voted as favorite addresses of international tourists. In 2018, the United Nations World Tourism Organization selected Vietnam as one of the world's 10 fastest-growing tourism destinations (World Tour Organization, 2019). 2019 was a successful year for Vietnam's tourism when it won a range of awards from World travel awards. While it was the second time that Vietnam was "Asia's leading destination", it was the first time that Vietnam was chosen as "World's leading heritage destination", "Asia's leading culinary destination" and "Asia's leading cultural destination". Moreover, Vietnam Airlines was recognized as "World's leading culture airline" and "World's leading airline Premium Economy Class” (World travel awards, 2019).

Tourism is being increasingly interested in the whole society. The quality and competitiveness of tourism are issues that receive a lot of attention and extensive discussion. A multi-dimensional approach to tourism quality assessment will contribute to forming the right solutions to improve the quality and competitiveness of Vietnam's tourism. Vietnam's tourism development strategy to 2020, with a vision to 2030 (Prime Minister, 2011) has set the overall objective of the tourism industry: By 2020, tourism will basically become a spearhead economic sector, accounting for an increasing proportion of the GDP structure, the more motivation for socio-economic development; towards professionalism, concentricity; parallel development of domestic and international tourism, with professionalism and relatively synchronous and modern technical and material system; Tourism products with high quality, diversity and branded.

By 2025, Vietnam has becomes an attractive destination, striving to be among the top three countries in tourism development in Southeast Asia and the top 50 countries with the world's leading tourism competitiveness, in which all 14 criteria of tourism competitiveness increased, in accordance with the requirements of sustainable development. There are specific objectives: Strive to receive at least 35 million international visitors and 120 million domestic visitors by 2025 , maintaining an average growth rate of international visitors from $12 \%$ to $14 \%$ per year and domestic tourists from $6 \%$ to $7 \%$ per year. The total revenue from tourists 
reaches from 77 to 80 billion USD, an average growth of $13 \%$ to $14 \%$ per year; Direct contribution to GDP reaches from $12 \%$ to $14 \%$, creating about 5.5 to 6 million jobs, of which about 2 million direct jobs, an average growth of $12 \%$ to $14 \%$ per year (Decision 147/QD-TTg on approval of Vietnam Tourism Development Strategy to 2030, 2020)

When tourism becomes a key economic sector, a target of economic development, the demand for human resources in this sector is high. With the current growth rate, the Vietnam National Administration of Tourism said that each year the sector needs 40,000 new employees and 25,000 employees need to be retrained. Meanwhile, every year the school only trains 20,000 students, of which the proportion of professionally trained tourism workers is still low, accounting for only $43 \%$ of the total tourism labor force, of which nearly one half do not know foreign languages. Because of low quality, labor productivity in tourism and hotel in Vietnam is only equal to 1/15 (one-fifteenth) of Singapore, 1/10 (one-tenth) of Japan and 1/5 (one-fifth) of Malaysia (Nhat Nam, 2019). Currently, the tourism human resource market is at risk of being "invaded" by human resources from regional countries such as Thailand, Singapore and Malaysia. After the establishment of the ASEAN Economic Community (AEC), Filipino, Thai, Indonesian, and Singaporean laborers came to Vietnam to work quite a lot, and almost every 4-5 star hotel had foreign workers. In fact, we need to pay more attention to human resources in the tourism sector in general and tourism and travel business in particular. Therefore, the study "Human resources for tourism and travel business in Vietnam" is very necessary and urgent in both theory and practice.

\section{Literature Review}

Tourism is one of the most important economic activities, considered a smokeless industry that directly creates services, products and foreign currencies, especially contributing to the increase of jobs and investment. This is considered a global industry that requires professional labor and generates diverse benefits (Sherap Bhutia, 2014). Human resources have a decisive role not only for the development of tourism but also contribute significantly to the development of the country's economy (Tom Baum, 2007). According to Sandra Herman (2015), the characteristics of the tourism industry highlight some important features of human resources in this field and the role of human resource development in supporting, improving productivity and quality in all levels in organizations, destinations and countries. Szivas (1999) stated that qualified and motivated workers can provide high quality services and gain competitive advantage for companies and destinations. Therefore, human resource development is central to sustainable tourism-oriented tourism initiatives (Sherap Bhutia, 2014).

An argument made by Ramona Gruescu et al. (2008) argues that tourism is a "multi-industry" field and this results in a more diverse career in the tourism sector. In addition, many experts believe that tourism personnel need high qualification, intensive knowledge, good training, foreign language skills and the ability to introduce and promote tourism products. In another viewpoint, experts also assessed that tourism in some market segments does not require too high specialization as some areas of tourism in agriculture, rudimentary industry, and so on. The professional requirements combined with the seasonal nature of the tourism industry 
have explained the viewpoint of new job needs, which is considered an outlet for unqualified and substandard workers (Ramona Gruescu et al., 2008). This shows that countries need to base on specific segments to effectively take advantage of tourism human resources in each different situation.

However, in the context of the current international economic integration, considering the status of jobs in tourism and upgrading based on a number of impacts has led to changes in the understanding about skills of human resources for the development of tourism (Tom Baum, 2007). These include: (1) the impact of environmental development on employment; (2) the impact of global and social forces on work and career perceptions; (3) The impact of information technology on tourism jobs and works. The higher the international integration, the more the linkage among countries is formed to create a global value added chain. All countries desire and are forced to participate more fully in the international division of labor. However, the level of participation of countries depends on the integration capacity, the availability and the level of labor.

Facing this problem, Pham Trung Luong (2016) also said that human resources in tourism need to be trained in skills and achieve widely recognized professional qualifications; it can be able to move and find jobs in the region and reach active participation in the international division of labor. In order to meet both the requirements of quality tourism human resources and market, the training needs to be carried out at all levels, whether managers, supervisors or subordinates, so as to have quality human resources to meet the requirements of maintaining facilities and providing services according to international standards (Sherap Bhutia, 2014). Meanwhile, Nguyen Manh Hung (2019) proposes three basic factors to develop tourism human resources: quantity growth, structure and quality of human resources development. In particular, the quality of tourism human resources considers factors such as knowledge, skills, experience, health, and so on.

Evaluating factors affecting tourism human resources development, Tran Son Hai (2011) refers to the level of development of the economy and tourism development; development level of education and training; macro-economic policies of the state (such as education and training policies, labor recruitment policies, salary policies, social insurance, so on); and other factors (such as globalization, the development of science and technology, information and communication). In fact, tourism human resource training is facing many big challenges, it lacks not only in quality but also in the number of tourism workers. Tourism human resource training institutions should be aware of the need for tourism human resources in a new context (Pham Xuan Hau and Nguyen Tan Trung, 2016).

\section{Methodology}

In order to achieve the research objectives in this study, the authors mainly used descriptive statistical methods to analyze the current situation of human resources in tourism and travel industry in Vietnam. In addition, the authors also conducted an analysis of the current situation of manpower training in tourism and travel business in Vietnam.

The authors collected secondary data and used SPSS 22 and Excel software to analyze and 
assess the current situation of human resources in tourism and travel business in Vietnam from 2000-2018. As a result, it points out the strengths and weaknesses of this workforce. At the same time, it assesses the current situation of the training of this workforce and points out the achievements and limitations that are existing.

\section{Research Results}

\subsection{Overview of Tourism Business Activities in Vietnam}

According to the World Tourism and Travel Organization (WTTC, 2017), the total contribution of Vietnam's tourism and travel business is 18.4 billion USD, accounting for $9.1 \%$ of the GDP, only ranked above Brunei, Myanmar and Indonesia in the ASEAN region. The share of Vietnam's exports from tourism accounts for only $4.5 \%$ of the total export value. Meanwhile, the proportion of contribution to GDP and the proportion of export value from tourism of countries such as Cambodia $28.3 \%$ and $26.5 \%$; Laos is $14.2 \%$ and $23.1 \%$; Myanmar is $6.6 \%$ and $26.4 \%$.

In the period of 2010 - 2018, Vietnam tourism has a strong growth in both the number of tourists and revenue. It took Vietnam 14 years, from 1994 to 2010 to increase from 1 million to 5 million international tourist arrivals; within the next 6 years, from 2010 to 2016, Vietnam had received 5 million tourists; and only within 2 years later, the number of international tourists has reached over 15 million. Similarly, the number of domestic visitors also increased rapidly during this period. In 2010, Vietnam had 28 million domestic visitors; after 5 years, this number had doubled to 57 million in 2015. Vietnam National Administration of Tourism affirmed that if this growth rate is maintained, Vietnam can completely catch up with the leading Asian countries in tourism such as Thailand, Malaysia and Singapore.

Table 1. Number of tourists coming to Vietnam and tourism revenue from 2000 to 2018

\begin{tabular}{|c|c|c|c|c|c|c|}
\hline \multirow{2}{*}{ Criteria } & \multicolumn{2}{|l|}{$\begin{array}{l}\text { Number of } \\
\text { domestic visitors }\end{array}$} & \multicolumn{2}{|l|}{$\begin{array}{l}\text { Number of } \\
\text { international visitors }\end{array}$} & \multicolumn{2}{|l|}{$\begin{array}{l}\text { Total revenue } \\
\text { from tourism }\end{array}$} \\
\hline & $\begin{array}{l}\text { Number } \\
\text { (thousand visitors) }\end{array}$ & $\begin{array}{l}\text { Growth } \\
(\%)\end{array}$ & $\begin{array}{l}\text { Number } \\
\text { (thousand visitors) }\end{array}$ & $\begin{array}{l}\text { Growth } \\
(\%)\end{array}$ & $\begin{array}{l}\text { Revenue } \\
\text { (trillion VND) }\end{array}$ & $\begin{array}{l}\text { Growth } \\
(\%)\end{array}$ \\
\hline 2000 & 11.200 & - & & & 17,40 & - \\
\hline 2001 & 11.700 & 4,5 & & & 20,50 & 17,8 \\
\hline 2002 & 13.000 & 11,1 & & & 23,00 & 12,2 \\
\hline 2003 & 13.500 & 3,8 & & & 22,00 & $-4,3$ \\
\hline 2004 & 14.500 & 7,4 & & & 26,00 & 18,2 \\
\hline 2005 & 16.100 & 11,0 & & & 30,00 & 15,4 \\
\hline 2006 & 17.500 & 8,7 & & & 51,00 & 70,0 \\
\hline 2007 & 19.200 & 9,7 & & & 56,00 & 9,8 \\
\hline 2008 & 20.500 & 6,8 & & & 60,00 & 7,1 \\
\hline 2009 & 25.000 & 22,0 & & & 68,00 & 13,3 \\
\hline 2010 & 28.000 & 12,0 & 5.050 & - & 96,00 & 41,2 \\
\hline 2011 & 30.000 & 7,1 & 6.014 & 19,1 & 130,00 & 35,4 \\
\hline 2012 & 32.500 & 8,3 & 6.848 & 13,9 & 160,00 & 23,1 \\
\hline 2013 & 35.000 & 7,7 & 7.572 & 10,6 & 200,00 & 25,0 \\
\hline 2014 & 38.500 & 10,0 & 7.874 & 4,0 & 230,00 & 15,0 \\
\hline 2015 & 57.000 & 48,0 & 7.944 & 0,9 & 355,50 & * \\
\hline 2016 & 62.000 & 8,8 & 10.000 & 25,9 & 417,20 & 17,3 \\
\hline 2017 & 73.200 & 18,1 & 12.922 & 29,2 & 541,00 & 29,7 \\
\hline
\end{tabular}




\begin{tabular}{|l|l|l|l|l|l|l|}
\hline 2018 & 80.000 & 9,3 & 15.498 & 19,9 & 637,00 & 17,7 \\
\hline 2019 & 85.000 & 6,0 & 18.008 & 16,2 & 726,00 & 16 \\
\hline
\end{tabular}

*According to new statistical methods

Source: Vietnam National Administration of Tourism, 2000-2018

In addition to the achieved achievements, Vietnam's tourism business has encountered many difficulties such as backward infrastructure and technical facilities for tourism, poor tourism products, problems of tourism resource exploitation and tourism environment pollution, the weaknesses of the tourism industry's human resources, so on. The cause of the above situation is due to the system of policies, management roles, team capacity has not met the requirements and more; also due to ineffective interdisciplinary coordination; the roles and responsibilities of all levels and branches from the central to local have not been fully promoted; awareness of tourism progression does not meet development requirements; tourism investment is limited and not effective as expected; a number of policies related to tourism are still inadequate, not timely removed difficulties for tourism businesses to improve competitiveness and attract tourists; security and safety issues for tourists are not guaranteed and so on.

\subsection{Situation of Human Resources for Tourism and Travel Business in Vietnam}

Regarding the scale of human resources, according to the report of the Vietnam National Administration of Tourism (2018), the total contribution of tourism to the national employment field (including indirect jobs) is more than 6,035 million jobs, accounting for $11,2 \%$. In particular, the number of direct jobs created by the tourism sector is 2,783 million (accounting for $5.2 \%$ of total employment). In addition, the human resource size of the tourism industry has significantly increased in recent years. In 2017, the total number of employees in this industry was 2,783 million, doubling compared to 2010 of 1,472 million. In line with this increase, the number of direct and indirect workers also increases. Especially, the growth rate of direct labor is faster than the number of indirect workers. This proves that the quantity of jobs created by the tourism industry for the society and careers related to tourism is very large, reflecting the role of the tourism and the effectiveness of socializing tourism activities.

Regarding the quality of human resources, with a specific feature of a service industry, the main activities are service, there are many areas that do not require high educational levels, so low-level direct labor (service, housekeeper, cleaning, tending bonsai, security staffs and more) accounts for a large proportion. This group of human resources has a high number of people who have not graduated from high school, accounting for $30 \%$ of the total workforce in the whole industry. This prediction continues to remain relatively high for a long time. Employees graduated from high school are mainly the group of professional, business administration human resources and professional activities and state management of tourism.

- Regarding training level: Manpower with primary, intermediate and college training in tourism is the labor force directly serving customers and providing tourism products, 


\section{Macrothink}

accounting for $47.3 \%$ of trained human resources, equal to $19.8 \%$ of the total workforce. Human resources trained in tourism from university and postgraduate account for $7.4 \%$ of the number of employees with tourism expertise, equal to $3.2 \%$ of the total workforce. The number of qualified human resources as above in tourism is low compared to the need for development and international integration. Manpower below elementary level (vocational training, less than 3 months) accounts for $45.3 \%$ of professional human resources, equal to $19.4 \%$ of the total workforce of the whole industry (Decision No. 1060 / QD-BVHTTDL on approving the Project "Strategy for developing human resources for culture, sports and tourism 2011-2020", 2011)

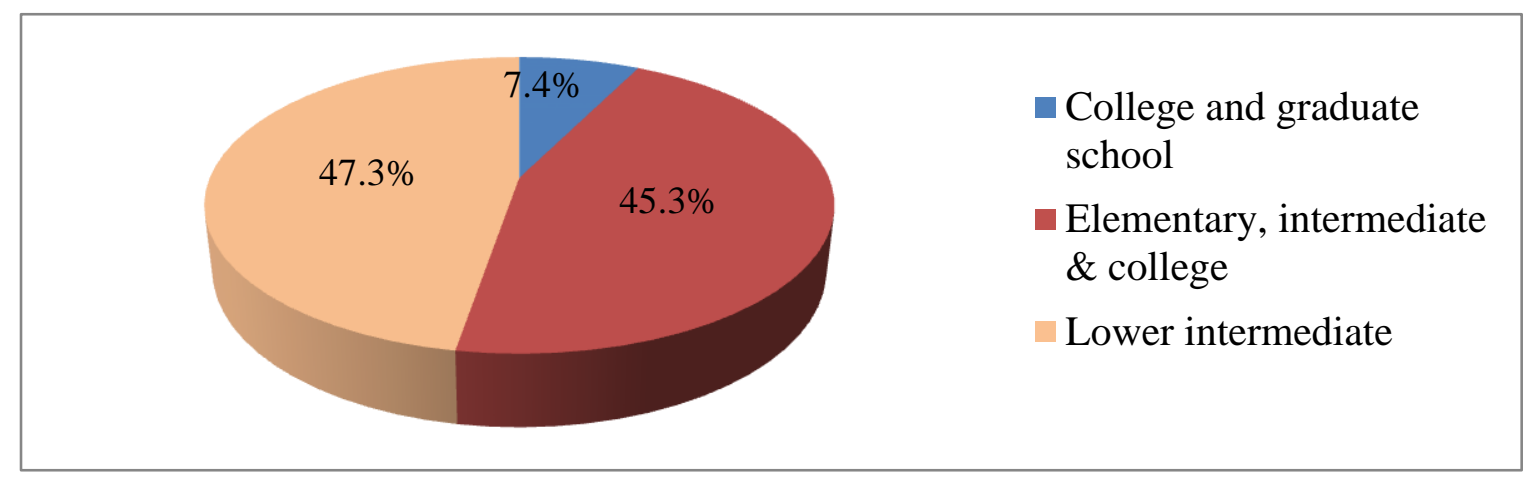

Figure 1. Structure of tourism labor training qualification

Source: Vietnam National Administration of Tourism

- Foreign language proficiency: Tourism is an industry that requires a large number of foreign language proficiency. The percentage of tourism employees using foreign languages in Vietnam is 60\%; in which the proportion of human resources using English is the highest, accounting for about $42 \%$ of the total workforce. Manpower use Chinese, French and other languages at 5\%, 4\% and 9\% respectively. (Decision No.1060/ QD-BVHTTDL approving the Project "Strategy on development of human resources for culture, sports and tourism 2011-2020", 2011)

Currently, the tourism industry in Vietnam is focusing on exploiting tourists from China, Japan, South Korea and Germany. Therefore, it is necessary to expand the training of foreign languages of the above countries besides English. The number of tourists from China and Chinese-speaking tourists visiting Vietnam annually accounts for 30-40\% of the total number of international visitors to Vietnam, so fluent in Chinese, knowledge of Chinese culture and character will be a favorable condition and required requirement to continue attracting this market of more than 1.2 billion people. 


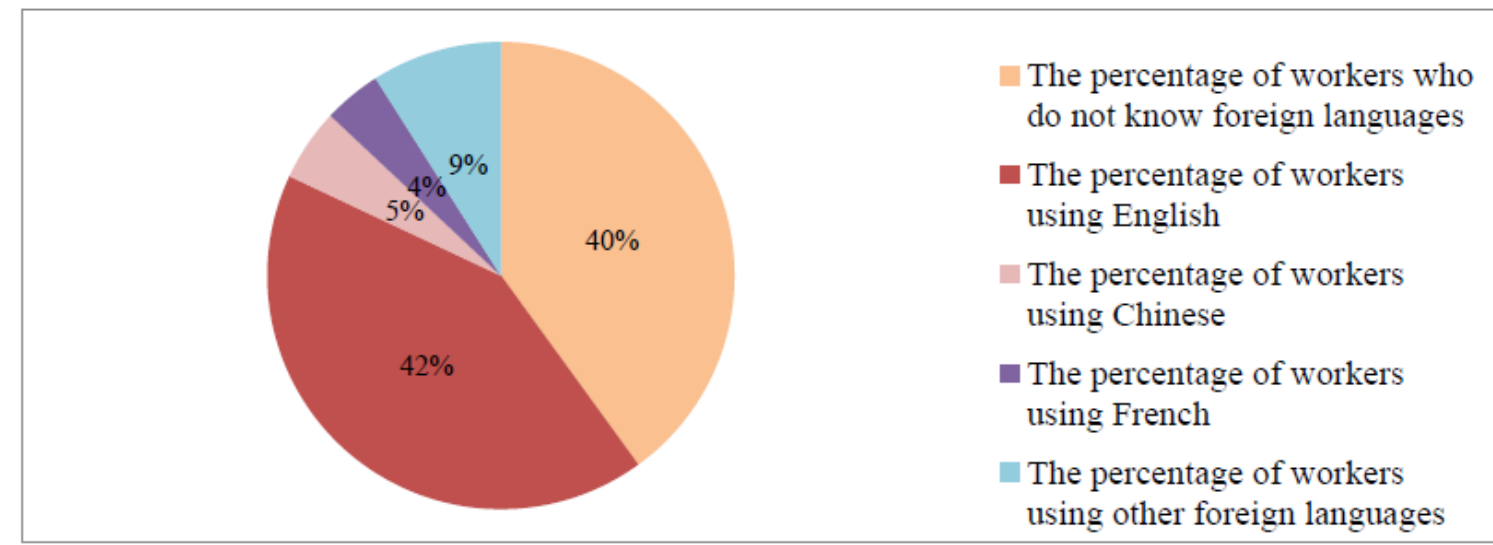

Figure 2. Tourism industry structure uses foreign languages

Source: Vietnam National Administration of Tourism

- Informatics level: The quantity of tourism human resources who can use computers for work requirements accounts for about $70 \%$ of the total number of employees (Decision No.1060/ QD-BVHTTDL approving the Project "Strategy on development of human resources for culture, sports and tourism 2011-2020", 2011)

\subsection{Situation of training human resources for tourism and travel business in Vietnam}

Firstly, the scale of training, currently, the tourism sector is assessed as an industry that needs 2-3 times higher than other key industries such as education, health and finance. According to the statistics of the tourism, by the end of April 2019, the whole country had about 346 tourism training establishments from elementary to tertiary level (an increase of 62 training institutions compared to 2010 - is 284). (Forum "Vietnam Tourism Human Resources 2019”, 2019)

Looking at Table 2, we can see, the enrollment index for the tourism sector of the universities has increased slightly or equal to the previous year. The rate of graduates having jobs after 1 year reaches from $80 \%$ to $95 \%$. These are the numbers that tell us the need and the "hot" level of the current tourism manpower in Vietnam. 
Table 2. Enrollment targets and the percentage of graduates having jobs after 1 year of some tourism training institutions

\begin{tabular}{|l|l|l|l|l|l|l|}
\hline \multirow{2}{*}{ No } & Name of university & \multicolumn{3}{|c|}{ Admissions criteria } & The percentage of graduates \\
\cline { 3 - 6 } & & $\mathbf{2 0 1 6}$ & $\mathbf{2 0 1 7}$ & $\mathbf{2 0 1 8}$ & $\mathbf{2 0 1 9}$ & having jobs after 1 year \\
\hline 1 & National University of Economics & 190 & 190 & 200 & 180 & $96 \%$ \\
\hline 2 & Thuongmai University & 290 & 450 & 450 & 400 & $93 \%$ \\
\hline 3 & Hanoi University & 75 & 135 & 160 & 160 & $93,4 \%$ \\
\hline 4 & $\begin{array}{l}\text { University of Social Sciences and } \\
\text { Humanities (Hanoi National University) }\end{array}$ & 150 & 150 & 170 & 170 & $93 \%$ \\
\hline 5 & Hanoi University of Culture & 470 & 470 & 470 & 525 & $90 \%$ \\
\hline 6 & $\begin{array}{l}\text { HCM University of Social Sciences and } \\
\text { Humanities }\end{array}$ & 200 & 200 & 200 & 150 & $91 \%$ \\
\hline 7 & Duy Tan University - Da Nang & 500 & 500 & 500 & 800 & $90 \%$ \\
\hline 8 & $\begin{array}{l}\text { University of Economics Danang } \\
\text { University }\end{array}$ & 240 & 195 & 260 & 165 & $96,6 \%$ \\
\hline 9 & Hue University & 550 & 600 & 600 & 900 & $89,73 \%$ \\
\hline 10 & Can Tho University & 270 & 280 & 360 & 320 & $90 \%$ \\
\hline 11 & Da Lat University & 120 & 200 & 200 & 200 & $81 \%$ \\
\hline
\end{tabular}

Source: According to the authors' group

In general, the schools are currently making great efforts in training tourism and travel business human resources to meet the requirements of society and integration, but factors such as: quality of enrollment entrance, frame and the prescribed training level, training program, learning materials, teaching methods and more, have a significant impact on the training process of the universities.

In fact, each year, specialized training schools on tourism only meet $60 \%$ of the industry needs, resulting in a serious shortage of tourism employees. According to the statistics of Vietnam National Administration of Tourism each year, the whole industry needs nearly 40,000 workers; but only about 20,000 employees graduated from training institutions, of which only about 1,800 university and professional college students, 2,100 tourism college students, and 18,200 intermediate level students, in addition, there are about 5,000 primary and less than 3 months vocational training. These figures show that human resources are not only lacking in quantity but also seriously lack of well-trained staff.

\section{Second, quality and effectiveness of training}

According to the Global tourism competitiveness report 2019 (World Economic Forum, 2019), Vietnam ranked 63th out of 140 countries in terms of competitiveness in tourism and travel business, in which the index human resources and labor markets ranked 47.

Labor resources in the field of tourism are not only lacking in quantity, but also weak in expertise. In Vietnam, there is no university that asserts that the quality of training in the industry meets the requirements of international corporations. Some schools have associated programs with large hotel groups but the curriculum is more theoretical but lacks practice. Graduates will not have much intensive experience to handle the job professionally. 


\section{Macrothink}

This leads to the fact that the human resources are trained but do not meet the requirements of big brands and if forced to recruit, businesses still have to retrain, causing a lot of difficulties in recruiting. According to a survey by Jobstreet (2013), in the field of tourism in Vietnam by the participation of more than 1500 young people with diplomas or not, of which more than $90 \%$ have a tourism qualification in the process of finding a job, more than $60 \%$ of the survey respondents on the level of the response of knowledge in class to the tourism industry work said that knowledge at the school is not sufficient to meet practical requirements of the job.

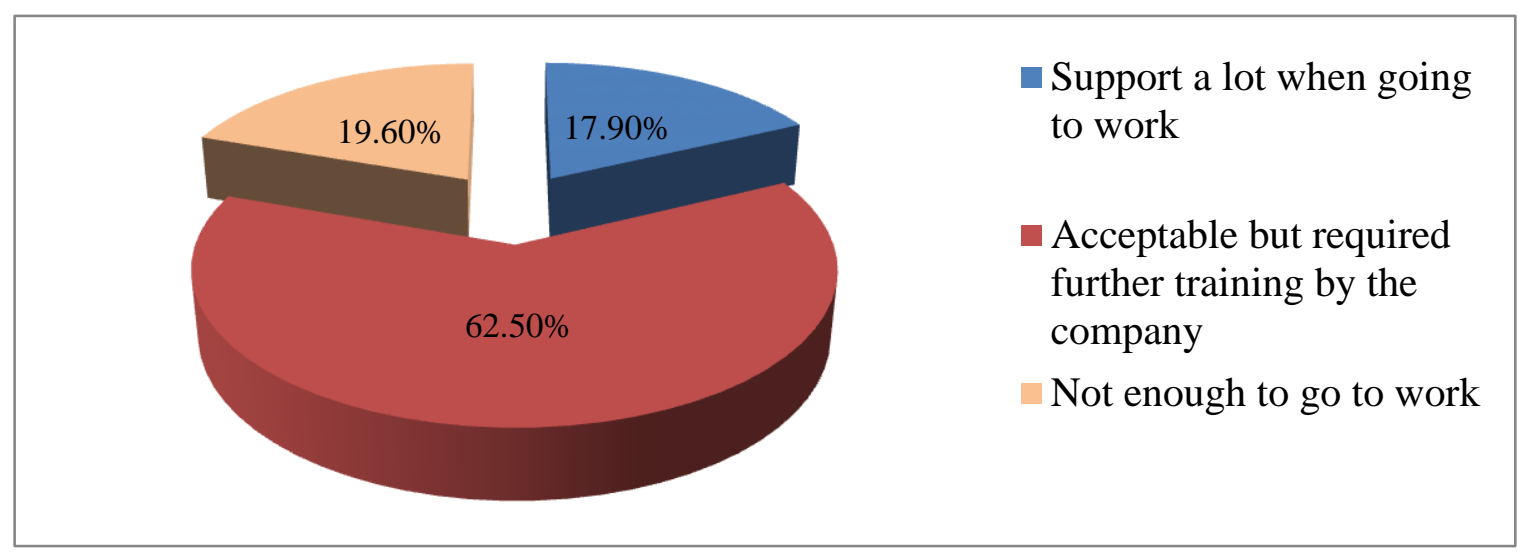

Figure 3. Assess the level of response of knowledge in class to the tourism industry

Source: Jobstreet (2013)

In order to have the human resources to meet the requirements, enterprises in the tourism sector in Vietnam must invest significant expense to retrain employees when recruiting. In fact, on the recruiter side, there are also assessments on the quality of training students, trainees of tourism training institutions through scoring skills.

Looking at a chart that assesses the skills of students trained from tourism universities can see some basic skills such as: foreign language skills, communication skills or customers service skills and more are important keys for students of the tourism industry; we have only achieved the number of 70-80\%, while these skills were supposed to need to get near-perfect scores. Foreign languages and information technology are considered the key to integration, but this is a major weakness of Vietnam's tourism human resources. According to the actual survey statistics, more than half of the labor force working in tourism is weak in foreign languages, which is a huge limitation of Vietnam's tourism industry. 


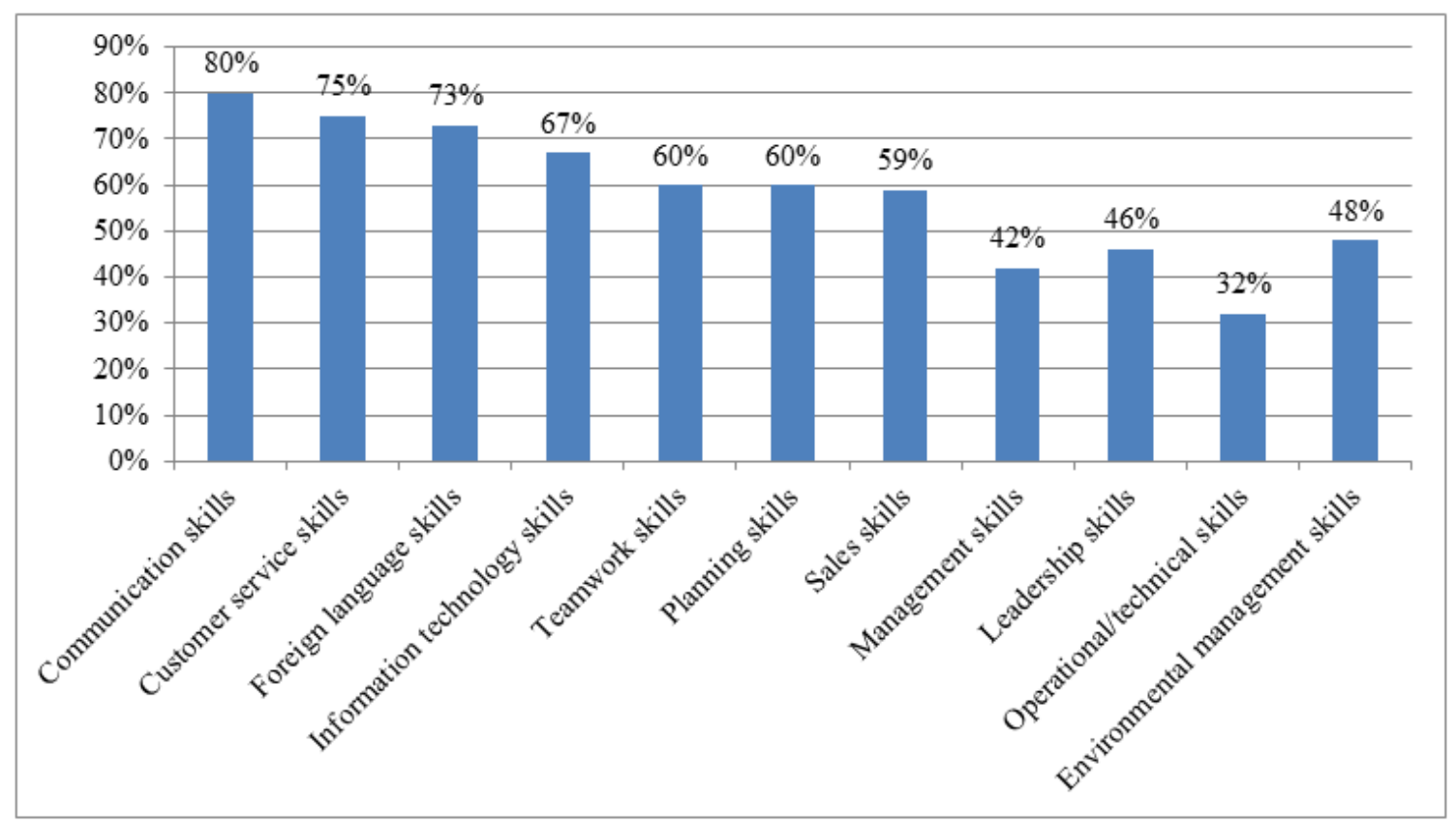

Figure 4. Satisfaction level of tour operators on university graduates' skills in tourism Source: Vietnam National Administration of Tourism (2013)

\subsection{General Assessment of Human Resources for Tourism and Travel Business in Vietnam}

\section{* Strength}

- Acquiring the historical tradition of the country, it is a tradition of hard work, diligence, hard work, love of labor, and rapid acquisition of scientific and technological advances of the world.

- Being trained, challenged, having strong political spirit; dynamic and creative.

- The level of knowledge, professional skills and capacity of state management, research, training, business administration have been improved.

- Human resources of the state management and tourism career have been developing their capabilities, using the trained knowledge and accumulated experience in the job.

- Manpower of tourism and travel business are hard-working and dynamic; eager to learn, professional capacity, foreign language skills, information technology and knowledge of international law are strongly progressive. Since then, productivity and labor efficiency are increased.

\section{* Weakness}

- The number of employees in tourism and travel business is small, the structure is not synchronized and the practical capacity is not commensurate with the qualifications.

- Human resources for high quality are still lacking, integration knowledge, foreign languages, 
information technology; Limited creative capacity, leadership, management, administration and practical experience do not correspond to the development requirements of this industry.

- A small part is not actively learning, still afraid to learn, the results are not high; Lots of specialized fields lack a lot of manpower.

- Quality of management human resources in localities is still inadequate; manpower in new business sectors, new enterprises have not been adequately and methodically trained. In addition to the imbalance and lack of qualified staff in many fields, regional imbalance is also a big problem.

- Human resources of state management and tourism career have limited knowledge, leadership capacity, management; updating of theoretical and practical information is not timely and not regularly attached to the facility. Some are not bold in social criticism, lack of cooperation and coordination. There is a phenomenon that good public servants and officers spend working in enterprises; being attracted or leaving to find jobs in localities with more favorable economic conditions or large urban centers, creating a shortage of highly qualified workers for localities.

- Manpower of tourism and travel business division still exists a part of employees with little experience, limited capacity and inefficient business.

- Staffs for tourism and travel business division in enterprises of different economic sectors have relatively large skill levels. Especially human resources in foreign-invested joint venture enterprises and state-owned and private enterprises.

\subsection{Assessment of Human Resource Training Activities in Tourism and Travel Business}

Over the past time, our Party and State have identified education as a leading national policy, institutionalized in the Education Law, Vocational Training Law and other priority policies, encouraging and supporting development in general and tourism manpower in particular. Tourism Law, tourism development policies, programs and schemes all consider tourism human resource development as one of the priority focuses. The sectors and levels have been gradually aware of the role of employees in tourism development management and are a key factor determining the quality of tourism services. Human resources training in tourism and travel business have achieved remarkable achievements.

Firstly, providing a large workforce with young age or industrious, hard-working, smart, skillful, motivated and studious quality, flexible behaviors in the face of market fluctuations and integration requirements.

Secondly, the network of tourism education and training at all levels is quickly formed to meet market request. The system of training facilities has been strengthened both in quantity and training capacity.

Thirdly, facilities, teaching and learning equipment, especially vocational skills educating at training institutions specializing in tourism gradually improve. The system of programs and frameworks for major tourism occupations at the college or lower level is formulated and 
uniformly applied; 13 VTOS occupational skills standards have been issued and applied; evaluation system and professional tourism certificates will accelerate the process of training, vocational transmission and tourism certification.

Fourthly, the number of tourism teachers, lecturers and trainers has been increasing in quantity and strengthened in terms of professional qualifications, foreign languages and integration knowledge and skills. Domestic and international joint programs, fostering programs, development programs for trainers and professional exchange forums have been continuously conducted to build a generation of tourism teachers, lecturers and trainers who grow in both quantity and quality.

Fifthly, the dynamism and diversification of training forms, socialization of mobilizing many resources for tourism training and retraining, especially on-site training at enterprises, self-training and transmitting through professional supervision, trainers have quickly overcome the shortcomings and weaknesses in professional knowledge and skills in some fields and tourist areas and destinations.

Sixthly, the experience of developing human resources domestically and internationally is transferred and absorbed selectively and quickly through many manpower development, tourism development projects, and foreign direct investment projects.

Besides, human resource training activities also face many difficulties.

Firstly, there are still many shortcomings in developing a system of curriculum and training programs. Up to now, tourism industry training program has not been agreed. The structure of the training curriculum framework varies widely between institutions, with a high percentage of general and specialized knowledge. There are institutions that are too geared towards skills and do not care to improve background knowledge, so only create a team of "workers" and cannot create good managers. In contrast, there are training facilities with low teaching practice, which leads to weak vocational skills of students.

Programs and training systems and are also inconsistent among schools, leading to "non-recognition". If students graduating from intermediate school or college at this school want to transfer tertiary education at other schools, they have to study additional courses which are time-consuming and expensive. As for continuing education from vocational schools to the system of colleges and universities faces many difficulties, graduates of vocational schools who are highly evaluated for management and administration capacity also face obstacles in promotion due to lack of qualifications.

In addition, the massive development of tourism training institutions while the lack of specialized teachers, the system of training institutions has led to legitimize the names of specializations in different ways. For example, some schools in the humanities have the name: Tourism studies, Vietnam studies ...; Economic and technical schools take the name: Travel and Tourism Service Management, Hotel and Tourism Business Administration and more. The consequence of this situation is that the name of the diploma is also different, causing confusion employers. 
The inconsistency in the teaching program and content makes the quality of tourism human resources at training institutions very different. This is also the reason why businesses are confused when relying on qualifications to recruit personnel.

Second, the educational management system is still overlapping. Currently, the management system of training facilities is fragmented, overlapping and different. The educational training institution is directly under management of the Ministry of Education and Training; vocational training institution under the management of the Ministry of Labor, War Invalids and Social Affairs. Meanwhile, the regulations on enrollment, training, testing, teacher standards and more are made by the two ministries separately; one training side by credit, one training by subject. This leads to a difference in learners' competencies at the output.

Thirdly, the contingent of lecturers and trainers is still deficient and weak. Currently, there are about 5,000 people participating in tourism training, including 2,000 lecturers and teachers, 2,580 trainers and 540 managers, serving training at all levels. Of the 2,000 lecturers and teachers as estimated, only 259 have a master's degree or higher (accounting for $13 \%$ ). Compared to other training disciplines, this is a very low rate.

Fourthly, career orientation work has not been methodically performed.

Most students take university and college entrance exams at their parents' requests, but not really love their chosen profession, so they are not interested in the job, resulting in a very high rate of graduates going to do opposite job. Because there is also no career orientation, the ratio of male and female in the tourism industry is quite large, up to $80 \%$ of students studying tourism are women. Therefore, their age is quite short, which disturbs the tourism market.

Fifth, the "output" issue is not guaranteed.

The problem of "output" with students studying at tourism training institutions has not been guaranteed, leading to attraction for those who have good ability to study is not much. Students have lacked career advice from the enrollment stage, resulting in a lack of orientation, choosing jobs that do not match their capacity. Most of the training institutions do not have a strategy to link with tourism businesses, so the situation of one-sided training schools and businesses need a different path. The business is the main output guarantee for students but the relationship between the training institution and the tourism enterprise is still unclear about the benefits, leading to the fact that most businesses associate with personal training institutions.

Sixth, training does not meet social needs.

Recently, although the human resources for tourism has developed in terms of scale and quality, it has not yet met the needs of society. In fact, the annual number of specialized graduates from training institutions only meets $60 \%$ of the needs of society. Besides, according to Professor Michael Palmer of RMIT Vietnam, "Vietnam tourism industry currently has only $3-4 \%$ of trained human resources and is lacking a large number of manpower in the position of supervision, middle and senior management". In reality, most of 
the titles of general directors of reputable tourism businesses are now undertaken by foreigners.

Seventhly, facilities and techniques in training are limited.

Most of the technical infrastructure of the schools in Vietnam today is still quite sketchy, not meeting the requirements of high quality training. For example: the school's area is too small, resulting in few lecture halls, the large number of students on classrooms that affect the quality of teaching. The number of practice facilities at the schools is very small (mainly in vocational schools, universities almost do not have) so students have very few opportunities to approach reality.

The above situation, according to tourism experts, is mainly because our country is lacking a training system in the field of tourism and the training capacity of tourism units is still inadequate.

Together with the current status of tourism training, there is still a big gap in quality compared with the requirements of businesses and society. Especially in the context of Vietnam joining the ASEAN Economic Community (AEC), this will be a challenge for Vietnamese tourism manpower if they do not have similar qualifications and quality. Therefore, at least in order not to lose right at home, the tourism industry needs to have quick solutions and strategies in training human resources.

\section{Some Recommendations}

\subsection{Some Solutions from the State}

Firstly, strengthening the state management of human resource training in tourism and travel business

State management agencies in charge of tourism should: Develop and organize the implementation of legal documents, mechanisms and policies on management of training, retraining, using and remuneration of human resources in tourism and travel business; Improving capacity of tourism managers; Developing a contingent of officials specialized in tourism human resource training; Closely coordinating between state management agencies in charge of tourism at the central and local levels in training employees for tourism; Strengthen examination and inspection of training and retraining activities to develop manpower for the tourism industry nationwide.

\section{Secondly, to build and unify standards of tourism occupational skills}

The goal of the solution group is to formulate a system of national standards on tourism human resources as a basis for training institutions to develop standard teaching programs and enterprises to recruit, use and treat their employees throughout the country and successful international integration.

\section{Thirdly, develop a network of tourism training and retraining institutions}

The objective of this group of solutions is to improve the capacity of tourism industry 
teaching and fostering for the network of tourism training and retraining institutions nationwide to meet social needs. Specific solutions: Re-planning the network of tourism training establishments; Prioritize investment in tourism-specialized training institutions; Interested in other training institutions that provide tourism teaching and diversify tourism training institutions

Fourthly, promote the application of advanced science and technology in research and statistics for tourism training and retraining.

- Enhancing the statistical work and scientific research on human resource development in Tourism;

- Investing in facilities, application equipment and effective exploitation of information technology to promote the training of tourism manpower

- Establishing and operating a database of tourism human resources to forecast and orient and manage tourism manpower training according to social needs.

Fifthly, strengthening the mobilization and efficient use of resources for training human resources in tourism and travel business.

- Develop a list of tourism human resource development projects to mobilize ODA, FDI and other forms of investment. Effectively use the projects that are being implemented and formulated and receive other projects for the development of tourism employees.

- Create favorable conditions for all members of society to participate in the development of tourism manpower and contribute to building material facilities, teaching and learning equipment, and provide suggestions for tourism human resource training plans

- To mobilize gray matter for human resource development in tourism: concentrate and effectively use the knowledge and experience of top 50 domestic scientists, overseas Vietnamese and foreigners to develop manpower development in tourism.

In addition, the State needs to create a favorable environment for human resource development in tourism and travel business through propaganda activities to raise people's awareness about tourism development responsibility; Enhancing image of tourism career; Expand and strengthen links between state management agencies on tourism

\subsection{Some Solutions from the Training Institutions on Tourism}

\section{Firstly, correctly identify the training needs}

This is an important first step in improving the teaching strategy and developing manpower for training institutions. In order to identify the need for training human resources in tourism and travel business management, training establishments may base on: Forecasting tourism human resources demand, Training objectives of the facilities, Factors of current training capacity.

Secondly, continue to perfect the training method 
Tourism is a field that requires employees to have high practical and professional skills, in other words, learners must work immediately after graduation. Therefore, the teaching methods of the schools also need to change, prioritize more time for professional practice or supplement soft skills and especially foreign language skills.

\section{Thirdly, build a good training program}

The training program should be in line with regional and international training standards. Accordingly, it is necessary to refer and learn international experience in developing curricula and textbooks. In the process of developing training frameworks or programs at all levels, it is indispensable to invite experienced international experts and lecturers to join them

\section{Fourthly, continuously improve the quality of lecturers}

Tourism teachers, lecturers and trainers should ensure adequate quantity, reasonable structure, quality standards to meet training needs, increase scale, improve quality and effective training and fostering human resources for tourism. Paying attention to raising the level of information technology, foreign languages and teaching methods so that tourism lecturers, teachers and trainers can teach, self-study and exchange professional knowledge directly with foreign experts as well as participate in conferences, seminars, international forums and study abroad. In addition, there is also a mechanism to attract the active participation of qualified managers, scientists, experienced entrepreneurs, artisans, experts, technicians with high vocational skills in teaching activities to improve the practicality of tourism training programs.

\section{Fifth, improve and enhance the quality of facilities and learning equipment}

In order to implement this solution, training establishments should pay attention to:

- Increase budget for upgrading and expanding training facilities; Invest in modern machinery and equipment for the classroom; Ensure the number of students or classrooms is not overloaded.

- Additional facilities, practice areas for students, such as tourism counseling centers, practice areas of hotel - restaurant, reception and so on.

- Develop an electronic library for lecturers and students to easily access the reference system.

\section{Sixth, strengthen links and cooperation in training and development}

In order to improve the openness as well as the quality of tourism training, there should be a mechanism to encourage joint training and training links, exchange of experience between domestic tourism teaching institutions and reputable travel training facilities abroad. Paying attention to creating mechanisms and encouraging the development of link models of tourism training establishments and tourism business, especially foreign joint-venture enterprises or companies with $100 \%$ foreign-owned prestige and brand. This linkage model is especially meaningful for tourism vocational intermediate levels because students will have the opportunity to practice in an international-class tourism service environment. 


\section{Conclusion}

Human resources are the determinant of all activities - this "truth" is often mentioned and affirmed in every aspect from a small organization to a large country, from a region to the global. Therefore, the training and retraining of human resources are always the top priority in any organization in the process towards development.

The teaching and fostering of manpower for tourism and travel business in Vietnam still face shortcomings that need to be addressed. Therefore, in order for the human resources of Vietnam's tourism and travel business industry to meet the requirements of society and integration, in the coming time, it is necessary to synchronize solutions, from the directional solutions as unifying the perceptions of related subjects on tourism manpower to the actions of the units, organizing training and fostering tourism human resources. At the same time, it is necessary to have a close cooperation between the stakeholders involved with agencies, units and ministries in the implementation.

\section{References}

Jobstreet. (2013). Survey on Vietnam's tourism industry.

Nhat Nam. (2019). Nhân lực ngành du lịch: Cầu tăng, cung chưa đáp ứng [Tourism human resources: demand has been increasing but supply has not been meeting the need]. [Online] Available: http://vietnamtourism.gov.vn/index.php/items/29687

Nguyen Manh Hung. (2019). Phát triển nguồn nhân lực du lịch cho các tỉnh trung du, miền núi Bắc Bộ [Developing tourism human resources for the Northern midland and mountainous provinces in Vietnam]. Doctoral dissertation, Thuongmai University, Hanoi, Vietnam.

Minister of Culutre, sport and tourism. (2011). Quyết định số 1060/QĐ-BVHTTDL ngày 29/03/2011 phê duyệt "Đề án chiến lược phát triển nhân lực văn hóa, thể thao và du lịch 2011-2020" [Decision No. 1060/QD-BVHTTDL dated 29 Mar, 2011 approving "Strategic project on development of culture, sport and tourism human resources during the period of 2011-2020] (Vn.)

Prime Minister. (2011). Quyết định số 2473/QĐ-TTG ngày 30/12/2011 phê duyệt "Chiến lược phát triển du lịch Việt Nam đến năm 2020, tầm nhìn đến năm 2030" [Decision No. 2473/QD-TTG dated 30 December, 2011 approving "Strategy on Vietnam's tourism development until 2020, vision to 2030"] (Vn.)

Pham Trung Luong. (2016). Đào tạo và phát triển nguồn nhân lực du lịch trong bối cảnh hội nhập [Training and developing tourism human resources in the context of integration]. Brexit và cộng đồng kinh tế ASEAN dưới góc nhìn hội nhập [Proceedings of the Brexit and ASEAN economic community from an integration perspective], Van Hien University. pp. 88-96.

Pham Xuan Hau and Nguyen Tan Trung. (2016). Giải pháp đào tạo nhân lực du lịch chất lượng cao của trường đại học Văn Hiến đáp ứng yêu cầu hội nhập. [Solutions to training high-quality tourism human resources of Van Hien University to meet integration requirements]. Brexit và cộng đồng kinh tế ASEAN dưới góc nhìn hội nhập [Proceedings of 
the Brexit and ASEAN economic community from an integration perspective], 97-106, Van Hien University.

Prime Minister. (2020). Quyết định số 147/QĐ-TTG ngày 22/01/2020 phê duyệt "Chiến lược phát triển du lịch Việt Nam đến năm 2030” [Decision No. 147/QD-TTG dated 22 January, 2020 approving "Strategy on Vietnam's tourism development until 2030”] (Vn.).

Ramona Gruescu et al. (2008). Human resource management in the tourism industry. Bulletin UASVM, Horticulure, 65(2), 168-173. http://dx.doi.org/10.15835/buasvmcn-hort:914

Sandra Herman. (2015). Management of Human resources in tourism. Interdisciplinary Management Research, Josip Juraj Strossmayer University of Osijek, Faculty of Economics, Croatia, 11, 180-188.

Sherap Bhutia. (2014). The Role of Tourism for Human Resource Development in Darjeeling District of West Bengal, India. Tourism and Hospitality Management, 2(1), 113-128

Szivas, E. (1999). The Influence of Human Resources on Tourism Marketing. In F. Vellas, \& L. Bécherel (Eds.), The International Marketing of Travel and Tourism: A Strategic Approach. London: Macmillan. https://doi.org/10.1007/978-1-349-27486-4_5

Tom Baum. (2007). Human Resources in Tourism: Still Waiting for Change. Tourism Management, 50(6), 1383-1399. https://doi.org/10.1016/j.tourman.2007.04.005

Tran Son Hai. (2011). Phát triển nguồn nhân lực ngành du lịch khu vực Duyên hải Nam Trung Bộ và Tây Nguyên [Developing human resources for tourism industry in the South Central Coast and Central Highlands regions in Vietnam], Doctoral dissertation, National Academy of Public Administration, Hanoi, Vietnam.

Vietnam National Administration of Tourism. (2000-2018). Tourism statistics. [Online] Available: http://vietnamtourism.gov.vn/english/

Vietnam Tourism human resources forum 2019 (12 April, 2019). Đào tạo nguồn nhân lực du lịch Việt Nam để phát triển ngành kinh tế mũi nhọn [Training Vietnamese tourism human resources to develop a key economic sector]. Ho Chi Minh City, Vietnam.

World Economic Forum. (2019). The Travel \& Tourism Competitiveness Report 2019: Travel and Tourism at a Tipping Point. WEF, Geneva.

World Tourism Organization. (2019). International Tourism Highlights, 2019 Edition. UNWTO, Madrid. http://doi.org/10.18111/9789284421152

World Travel Awards. (2019). World nominees 2019. [Online] Available:

https://www.worldtravelawards.com/nominees/2019/world

World Travel Awards. (2019), Asia nominees 2019. [Online] Available:

https://www.worldtravelawards.com/nominees/2019/asia

World Travel \& Tourism Council. (2017). Travel \& Tourism Economic Impact 2017 Vietnam. WTTC, United Kingdom. 


\section{Copyright Disclaimer}

Copyright for this article is retained by the author(s), with first publication rights granted to the journal.

This is an open-access article distributed under the terms and conditions of the Creative Commons Attribution license (http://creativecommons.org/licenses/by/4.0/). 